\title{
A Comparative Analysis of Institutions Responsible for the Election of Judges in France, Germany and Poland
}

\begin{abstract}
The paper presents a comparative analysis of the institutions responsible for the election, promotions and nominations of judges in France, Germany and Poland. At the very beginning - in the introduction - the genesis of institutions which are equivalents of the National Council of the Judiciary ${ }^{2}$ was presented, starting from the philosophical basis for the idea of the independence of courts and judges, through international regulations to the constitutions of individual states. The main part was divided into 3 sections: a brief description of the judiciary, the composition of the institution responsible for the election of judges and the manner of appointing its members, and the competence of the council and the manner of appointing judges. Each of these issues was divided by the selected countries, thanks to which it will be possible to get a clear picture of how these institutions work in individual countries. As a summary, conclusions about how the principle of judiciary independence is met in selected countries, and whether meeting this principle depends exclusively on legal framework.
\end{abstract}

Keywords: judiciary, Council of the Judiciary, election of judges

1 Krzysztof Pasierbek - student in Law College, Kozminski University; e-mail: krzysztof.pasierbek@ outlook.com; ORCID: 0000-0002-7607-102X.

2 Krajowa Rada Sądownictwa - KRS [translator's note]. 


\section{Introductory issues}

The principle of a democratic legal state functions in the constitutions of many modern democratic countries. The phrase "state of the law" was coined in the $19^{\text {th }}$ century in the German doctrine created by Robert Von Mohl ${ }^{3}$. However, it had an actual impact on the functioning of the state in 1949, when the Basic Law for the Federal Republic of Germany of 1949 was passed. ${ }^{4}$

It was formulated in Article $28^{5}$, which states that "The constitutional order of the Lands must correspond to the rules of a republican, democratic and social legal state $[. . .]^{\prime \prime}$. In the Polish Constitution, it is included in Article 2 "The Republic of Poland is a democratic legal state which implements the principles of social justice". ${ }^{78}$ This principle was also included in the Constitutions of such countries as Spain ${ }^{9}$ or Slovakia ${ }^{10}$.

A democratic legal state was also reflected in international regulations, such as the Treaty on the European Union ${ }^{11}$ (Article 2), where it is mentioned that "[ $\mathrm{t}]$ he Union is founded on the values of respect for human dignity, freedom, democracy, equality, the rule of law [...]". On this basis, it may be concluded that the states of the European Union which did not include the principle of a democratic legal state in their Constitutions explicitly support and realise it, as those countries adopted the Union regulations in their legal orders as they joined the European Union. The values included in Article 2 of the Treaty on European Union were deemed so essential that even a measure to secure compliance with those values was created. It was included in Article 7 of the above-mentioned treaty.

$3 \quad$ H. Izdebski, Doktryny polityczno-prawne, Warsaw 2017 p. 153.

4

L. Garlicki, Polskie Prawo Konstytucyjne, Warsaw 2017, p. 76.

5 Basic Law for the Federal Republic of Germany of 23 May 1949.

6 Own translation [translator's note].

7 Constitution of the Republic of Poland of 2 April 1997 (Dz.U. 1997 nr 78 poz. 483 / Journal of Laws of 1997 No. 78 item 483).

8 Own translation [translator's note].

9 Constitution of Spain of 27 December 1978.

10 Constitution of the Slovak Republic of 1 September 1992.

11 Official Journal of the European Union, 2008/C 115/01. 
One of the pillars of a democratic legal state which is considered standard nowadays is judicial independence ${ }^{12}$. This results from the modern understanding of the separation of powers (the principle of the separation of powers was also included in Article 10 of the Constitution of the Republic of Poland) - it was Montesquieu who pointed out in his treatise The Spirit of the Laws that there is no freedom when the judiciary power lacks independence from the executive power and the legislative power. The separation of powers is a form of restricting the government so that the power does not transform into totalitarianism and authoritarianism.

The principle of the separation of powers does not eliminate, however, associations between the judiciary power and the legislative and executive powers. Such an association can be found, for instance, in the competence of the Minister of Justice concerning the creation and abolition of courts. However, it is essential here that associations with the other powers do not interfere in the essence of the of courts and judges. ${ }^{13}$

Therefore, one should dwell on distinguishing the ideas of the independence of courts and the independence of judges. The views of the doctrine on this matter are different, however, one of them ${ }^{14}$ states that the aspect of the independence of courts includes the issue of functional independence (based on the separateness of the object of the activity) and of organisational independence (which involves one's own organisational structures), and the independence of a judge concerns the status of the judge himself or herself.

It should also be emphasised here that the violation of the independence of judges and courts is one of the most frequent practices of totalitarian and authoritarian governments against human rights. ${ }^{15}$

The independence of the judiciary and judges was also included in the Constitution of the Republic of Poland. Article 173 of the Constitution of the Republic of Poland states that courts and tribunals are a power independent from other powers. As defined by the Constitutional Tribunal, it is a ban on the interference of other powers in the basic "competence core" of courts, which is the exercise of justice. ${ }^{16}$ In turn, Article 178 of the Constitution of the Republic of Poland states that judges are independent in their positions and they are only subject to the

12 D. Zawistowski, Niezależność sądów i niezawisłość sędziów z perspektywy prawa Unii Europejskiej, „,Ruch Prawniczy, Ekonomiczny, Socjologiczny" 2016, No. 2, p. 8.

13 S. Dąbrowski, Władza sądownicza - definicja, funkcje atrybuty, in: Pozycja ustrojowa sędziego, ed. R. Piotrowski, Warszawa 2015, p. 25.

14 A. Łazarska, Niezawisłość sędziowska w sprawowaniu urzędu, Pozycja ustrojowa sędziego, R. Piotrowski, Warszawa 2015, p. 88.

15 Ibidem, p. 84.

16 Konstytucja. Komentarz, t. II, eds. M. Safjan, L. Bosek, Warsaw 2016, p. 968. 
Constitution and acts. Therefore, the principle of the independence of judges is included in this article. The Constitution of the Republic of Poland does not provide any definition of independence there, which did not prevent the doctrine and the case law from working out a relatively uniform voice. One of the definitions states that the independence of judges means the unacceptability of external interference or of exercising pressure on a judge to decide a case in any way. ${ }^{17}$

The independence of the judiciary was also widely reflected in international regulations. Such organisations as the United Nations, the Council of Europe or the European Union state it explicitly that an independent court is a standard and an integral part of a state of the law. The International Covenant on Civil and Political Rights ${ }^{18}$ states in Article 14 that "[...] everyone shall be entitled to a fair and public hearing by a competent, independent and impartial tribunal [...]", the Convention for the Protection of Human Rights and Fundamental Freedoms ${ }^{19}$ states in Article 6 that "everyone is entitled to a fair and public hearing within a reasonable time by an independent and impartial tribunal [...]", and the Charter of Fundamental Rights ${ }^{20}$ states in Article 47 that " $[. .$.$] Everyone is entitled to a fair and$ public hearing within a reasonable time by an independent and impartial tribunal [...]". Thus, judicial independence was considered one of the most important values of modern legal states, as this value is supported by the major international organisations. The Republic of Poland is associated with all the legal regimes mentioned in this paragraph.

Relying on the history of the Republic of Poland, it was concluded during meetings of the Round Table that the executive power could not safeguard the independence of courts and judges on its own, but appointing another institution was necessary. It is undoubtedly interesting that the institution of the National Council of the Judiciary was not provided for in the classic concepts of the separation of powers. The need for the creation of such an institution emerged when the system position of courts and the system of justice changed in a way. Traditionally, courts were supposed to administer justice on the basis of the law, with an emphasis on acts. However, an inherent extension of the competence of courts also to resolving axiological disputes and imposing the obligation to control the other powers

17 Ibidem, p. 1010.

18 International Covenant on Civil and Political Rights open for signature in New York on 19 December 1966 (Dz.U. 1977 nr 38 poz. 167 / Journal of Laws of 1977 No. 38 item 167).

19 Convention for the Protection of Human Rights and Fundamental Freedoms drawn out in Rome on 4 November 1950, then amended with Protocols 3, 5 and 8 and annexed with Protocol 2 (Dz.U. $1993 \mathrm{nr} 61$ poz. 84 / Journal of Laws of 1993 No. 61 item 84).

20 Official Journal of the EU C 83 of 30 March 2010. 
occurs currently. For this reason, it was required that an institution which would specialise in taking care of judicial independence be created ${ }^{21}$.

The realisation of the principle of the independence of courts is very difficult. Disputes concern bodies which should be equipped with competences for appointing judges, taking care of the independence of the judiciary and the judges. On the basis of the previously mentioned reflections on this matter, it was concluded that the solution to this problem would be the establishment of Councils of the Judiciary which should serve such functions. Recommendation (2010) 12, Judges: Independence, efficiency and responsibilities ${ }^{22}$, created by the Committee of Ministers of the Council of Europe, referring to Article 6 of the Convention for the Protection of Human Rights and Fundamental Freedoms, specifies that councils of the judiciary are independent bodies, established by law or constitutional regulations whose purpose is to protect the independence of courts and judges and thus to promote the effective functioning of the judiciary. This recommendation clearly defines the manner of perceiving the councils of the judiciary by international institutions such as the Council of Europe.

However, the manner of electing the members of National Councils of the Judiciary and which circles they should represent create further problems. Peculiar assistance in solving this problem can also be found in the previously mentioned Recommendation of the Council of Europe which states in Article 27, in turn, that not less than half the members of such councils should be judges chosen by their peers from all levels of the judiciary and with respect for pluralism inside the judiciary. This means no more and no less than the fact that a council should include representatives of all instances of courts and of all types of courts functioning in a given country. In this respect, the Recommendation allows for the sitting of representatives of other professions and other powers on the councils of the judiciary, but not more than half the council, concluding that this does not affect the idea of the independence and separateness of the judiciary power in relation to other powers and authorities. The Council of Europe also devised another document, called the European Charter on the Statute for Judges.

Moving to the Constitutions of individual states, the National Councils of the Judiciary (or bodies with competence attributed to such councils) were frequently reflected in the Basic Laws. In the Constitution of the French Republic ${ }^{23}$, Article 65 establishes the Superior Council of the Magistracy, or in the Constitution of the

21 P. Tuleja, Konstytucyjny status Krajowej Rady Sądownictwa, In: Jubileuszowa monografia XX-lecia Krajowej Rady Sądownictwa, ed. P. Tuleja, Torun-Warszawa 2010, pp. 62, 65-66.

22 Recommendation CM/Rec(2010)12 and explanatory memorandum https://rm.coe.int/16807096c1.

23 Constitution of the French Republic of 4 October 1958. 
Republic of Poland in which Article 179 establishes the National Council of the Judiciary as the body responsible for submitting candidates for judges to the President, and for safeguarding the independence of courts and judges (Article 186 of the Constitution of the Republic of Poland).

Initially, after the meetings of the Round Table, Poland was the first post-communist country to establish such an institution. The Republic of Poland was followed by such countries as i.a. Slovenia, Bulgaria or Hungary. ${ }^{24}$

It should be noted here that not all democratic legal states established the institution of the National Council of the Judiciary. Even the Federal Republic of Germany, a frequent model for other states when it comes to democracy, with the judgements of the Federal Constitutional Tribunal as the model of understanding the principle of a democratic legal state, did not establish such a council explicitly, appointing judges in a different way, which will be mentioned later in this paper. The National Councils of the Judiciary also do not always correspond to recommendations included in international law, such as the previously mentioned Recommendation 12 of the Council of Europe, which specifies that at least half of the NCJ should be judges - for instance, in France, on the Superior Council of the Magistracy (French: Conseil Supérieur de la Magistrature), 5 of 12 members are representatives of the judiciary. A detailed analysis will be included in the further part of this paper in which institutions serving the purpose of submitting candidates and nominating judges in Germany, France and Poland will be presented. The description of the institutions will be presented in the following formula: a brief description of the judiciary power, the institution responsible for the election of members and the manner of election, the competence of such an institution and conclusions.

\section{A brief description of the judiciary power}

\section{Federal Republic of Germany}

Chapter IX of the Constitution of the Federal Republic of Germany ${ }^{25}$ dwells on the most important judgements concerning the administration of justice. The judiciary power, which is also frequently called the third power, was divided into the Federal Constitutional Tribunal (which deals with, among other things, judgements as to the competence of the bodies in case of conflicts, and with investigating the compliance of the law of the Lands and of the federal law with the Constitution),

\footnotetext{
24 P. Tuleja, op. cit., pp. 61-62.

25 Basic Law for the Federal Republic of Germany of 23 May 1949.
} 
federal courts and courts of the federal states. Due to the fact that there are 16 Lands in the Federal Republic of Germany, attention will be paid mostly to the federal judiciary in this paper. And this judiciary, on the basis of Article 95 section 1 of the Constitution of Germany, consists of the Federal Constitutional Tribunal, the Federal Tribunal, the Federal Labour Court, the Federal Administrative Court, the Federal Court of Auditors and the Federal Social Court. The Constitution in Article 96 section 1 also allows for the establishment of a federal court for the protection of business activity, and military criminal courts - however, this was presented as an facultative aspect, which allows for an implication that these courts are not a fundamental part of the judiciary power of the Federal Republic of Germany.

As seen above, the supreme Courts and Tribunals were divided by the matter of cases. It follows that there is also such a division at lower levels. The divisions include: common courts and specialised courts. ${ }^{26}$ And here the division is shaped as in the case of the federal level. In terms of the common judiciary, it is divided into criminal courts and civil courts. In turn, the specialised judiciary is divided into administrative courts, financial courts, labour courts and social courts.

An undoubtedly interesting solution in the German judiciary is a three-stage proceeding. ${ }^{27}$ This principle, however, is not absolute because some areas of the judiciary only have two instances - e.g. financial judiciary (German: Finanzgerichtsbarkeit), where there is only the Financial Court, and the function of the second instance court is served by the Federal Court of Auditors.

A federal minister in charge of a given matter, and the committee for the appointment of judges (German: Richterwahlausschuss), which was established in Article $95^{28}$, are responsible for the appointment of judges.

\section{French Republic}

Chapters VIII and IX of the Constitution of the French Republic ${ }^{29}$ discuss issues related to the administration of justice. Article 64 states that the President of the Republic is a guarantor for judicial independence. In the same article, the Superior Council of the Magistracy (French: Conseil Supérieur de la Magistrature), by means of which the President complies with his or her constitutional obligation, is also

\footnotetext{
26 Website maintained by the European Commission, presenting a brief overview of the structure of the German judiciary https://e-justice.europa.eu/content_judicial_systems_in_member_states16-de-restore-pl.do?member $=1$

27 Website of the German Federal Ministry of Justice http://www.bmj.de/SharedDocs/Downloads/ EN/Schaubild_Gerichtsaufbau_Englisch.pdf?_blob=publicationFile

28 Basic Law for the Federal Republic of Germany of 23 May 1949.

29 Constitution of the French Republic of 4 October 1958.
} 
established. In the Constitution of France, in Article 65, the rules concerning the manner of choosing members for that institution is very firmly established, with an extremely detailed description of the composition of the Council. However, this will be described in more detail further in this paper.

In France, the judiciary may be divided into two sections: the juridicial order (French: Ordre Judiciairie) and the administrative order (French: Ordre Administratif). Within the juridical order, civil and criminal judiciary ${ }^{30}$ can be distinguished, within which even more specialised courts function. As seen above, the division of the judiciary in the French Republic is extremely thorough, with courts deciding quite a narrow scope of cases. Within the framework of the juridical order, there are two instances after which one can appeal in cassation to the Supreme Court (French: Cour de cassation), and within the framework of the administrative order, there are also two instances after which one can appeal to the Supreme Administrative Court (French: Conseil d'Etat). It should be noted that there are not always two instances in the administrative order - in cases such as e.g. a request for the annulment of the President's decree, the court makes a ruling in the first and last instance. Conflicts of competence between the administrative order and the juridical one are judged by Court for Resolving Conflicts (French: Tribunal des conflits). In the case of treason by the President of the Republic, the authority competent for the judgement is the Supreme Court of Justice (established in chapter IX of the Constitution, specifically in Articles 67 and 68).

\section{Republic of Poland}

In the Constitution of the Republic of Poland ${ }^{31,}$ courts and tribunals were discussed in chapter VIII. The independence of the judiciary power from other powers was clearly indicated, both in Article 10 concerning the separation of powers, and in Article 173. Article 175 states that the administration of justice is performed by the Supreme Court, common courts, administrative courts, and military courts. A clear division into common courts and specialised courts: administrative and military ones can be seen here. ${ }^{32}$ This is a so-called closed catalogue, which means that the Constitution of the Republic of Poland does not allow for the establishment of other specialised courts.

30 Website of the French Ministry of Justice http://www.justice.gouv.fr/organisation-de-la-justice-10031/

31 Constitution of the Republic of Poland of 2 April 1997 (Dz.U. $1997 \mathrm{nr} 78$ poz. 483/ Journal of Laws of 1997 No. 78 item 483).

32 L. Garlicki, op. cit., p. 388. 
The Constitution also includes a rule that a judicial proceeding should have at least two instances (Article 176). The division of instances in the Republic of Poland is shaped in the following way: at the lowest level, there are district courts, then regional courts, courts of appeal, and at the very top, there is the Supreme Court to which one is entitled to appeal in cassation against the judgements of courts of the lower instances. As far as the division of administrative courts is concerned, there are voivodship administrative courts and the Supreme Administrative Court.

When it comes to more important competences, the independence of the Polish Supreme Court is so essential that the institution processes potential electoral protests and decides the validity of elections.

Apart from the courts, Tribunals which do not administer justice in the strict sense were also included in the Constitution. ${ }^{33}$ There are two Tribunals and these are: the Constitutional Tribunal (which i.a. determines the constitutionality of normative acts and resolves disputes regarding competence) and the State Tribunal (a very politicised authority deciding cases which concern constitutional liability).

The National Council of the Judiciary is a body that is responsible for the protection of judges and courts and representing the interests of the judiciary power and acting as proxy in making the most important decisions by the executive power and the legislative power on the judiciary. ${ }^{34}$ This is a constitutional body which is discussed in Article 179 and Article 186 of the Constitution. An interesting difference between France and Poland can be seen here - in the former, the independence of judges and courts is safeguarded by the representative of the executive power, the President of France. In the Republic of Poland, a separate body was established to fulfil this constitutional obligation, though the President is supposed to watch over compliance with the Constitution (Article 126 section 2).

\section{The composition of the institution responsible for the election of judges, and the manner of appointing the members of that institution}

\section{Federal Republic of Germany}

Exact norms regarding the process of appointing federal judges (with the exception of the Federal Constitutional Tribunal) are included in the Federal Judicial

\footnotetext{
$33 \quad$ Ibidem, p. 386.

$34 \quad$ Ibidem, p. 396.
} 
Election Act - Richterwahlgesetz ${ }^{35}$. As mentioned above, the issue of appointing federal judges in the Federal Republic of Germany is dealt with by a federal minister in charge of a given matter, with a committee for the appointment of judges. The committee consists of 16 representatives of the Lands (who are ministers in charge of a given matter) and 16 members chosen by the Bundestag. The members elected by the Bundestag can - but do not have to - be members of the lower chamber of the federal parliament. Judges can also be such members, but it is not a requirement. The members representing the Bundestag are elected by preserving the balance of powers in the German lower chamber, therefore there is a representative of every group included in the lower chamber in this institution.

The Federal Constitutional Tribunal is characterised by another way of electing judges. First of all, it comprises 16 judges who are divided into two senates. ${ }^{36}$ They are elected for terms of 12 years half by the Bundestag and half by the Bundesrat. Importantly, there are higher requirements for voting in the case of the election of judges -8 of 12 Committee members in the case of the Bundestag and $2 / 3$ of votes in the case of the Bundesrat. This is a specific way to ensure pluralism in the election, for, with this requirement, the opposition usually also has to agree to a given candidate. It is also required that at least 3 members in each Senate have previously served as federal judges for at least 3 years. ${ }^{37}$

In the case of the committee for the appointment of judges, the solution adopted in Germany is extremely interesting but it raises many doubts. The committee for the appointment of judges is comprised in a highly politicised way. Politicians of the Lands constitute one half of the committee, and Bundestag politicians constitute the other half. A positive aspect of this solution is the fact that there are frequently different proportions of political powers in the Lands than in the Bundestag, which in a sense guarantees the pluralism of that institution. The lack of the compulsory presence of judges in the committee is, however, contradictory to i.a. the previously mentioned recommendation of the Council of Europe ${ }^{38}$ pointing out that in bodies competent for the election of judges, at least half of the composition should represent the third power.

\footnotetext{
35 German Federal Judicial Election Act - Richterwahlgesetz.

36 P. Sarnecki, Ustroje konstytucyjne państw wspótczesnych, Warszawa 2008, p. 206.

37 M.L. Volcansek, Appointing Judges the European Way, "Fordham Urban Law Journal" 2007, No. 1, Vol. 34, 2007, p. 378.

38 Recommendation CM/Rec(2010)12 and explanatory memorandum https://rm.coe.int/16807096c1
} 


\section{French Republic}

As far as France is concerned, the situation is more stabilised. As mentioned above, the issue of the Superior Council of the Magistracy were normalised in great detail in the Constitution of the French Republic itself ${ }^{39}$. Article 65 of the Constitution establishes the composition of the Council - the President of the Republic is the President of the Council ex officio, and the Minister of Justice is the Vice-President of the Council. An interesting solution is the establishment of two sections, one responsible for the election of judges, and the other responsible for the election of prosecutors. Especially the election of prosecutors is an undoubtedly different solution $^{40}$ (where, for instance, in Poland, since 2016, the Minister of Justice is ex officio the General Prosecutor). In the section responsible for the election of judges (it is they who are the main topic of this paper), apart from the previously mentioned President and the Minister of Justice, the members are 5 judges representing judicial self-government, 1 prosecutor, 1 privy councillor delegated by the Council of State, and 3 members who are neither representatives of the parliament nor of the judiciary, appointed by the President of the Republic, the President of the National Assembly (which is the lower house of the parliament) and the President of the Senate, respectively.

A constitutional court in France is the Constitutional Council. It consists of 9 members elected for a term of 9 years. 3 of those members are appointed by the President of France, another 3 members are appointed by the President of the National Assembly, and 3 members are appointed by the President of the Senate. Under the law, the Council is also comprised of the former Presidents of the Republic. An intriguing solution is the fact that there is no formal requirement that the members of the Council have a law degree. ${ }^{41}$ It is intriguing, but it also raises some concerns because one of the competences of the Council is ruling on the proper execution of the elections of the President of the Republic, which, given the lack of the law education requirement and the politicised nature of that Council, is a problematic solution. ${ }^{42}$

The solutions adopted in France which concern the Superior Council of the Magistracy are closer to the idea presented by the recommendation of the Council of Europe (however, they still do not meet it because the judiciary is represented

\footnotetext{
39 Constitution of the French Republic of 4 October 1958.

40 N. Garoupa, T. Ginsburg, The comparative law and economics of judicial councils, "Berkley Journal of International Law" 2009, No. 1, p. 73.

41 Website maintained by the European Commission, presenting a description of the Constitutional Council https://e-justice.europa.eu/content_specialised_courts-19-fr-pl.do?member=1.

$42 \quad$ M. Volcansek, op. cit., p. 380.
} 
by 5 out of 12 members). What can also be seen here is a very strong focus on the idea of the separation of powers, with an emphasis on the independence of the judiciary. One of the reasons for this state of affairs is undoubtedly the fact that France made many changes to the Constitution, testing various solutions on its system. The section referring to prosecutors is also a unique solution, but it does not have such competences as the section concerning judges.

\section{Republic of Poland}

As mentioned above, the National Council of the Judiciary, which is supposed to safeguard the independence of courts and judges, was established in Poland. Article 187 of the Constitution defines precisely what the composition of the Council should be ${ }^{43}$. The Council includes: the First President of the Supreme Court (who is appointed by the President of the Republic of Poland for a term of 6 years out of the candidates submitted by the General Assembly of the Judges of the Supreme Court), the President of the Supreme Administrative Court (the election is analogous to the one in the case of the First President of the Supreme Court), the Minister of Justice, a person appointed by the President of the Republic of Poland, 4 members chosen from deputies by the Sejm, 2 members chosen from senators by the Senate, and 15 members chosen from the judges of the Supreme Court, common courts, administrative courts and military courts. Thus, the National Council of the Judiciary comprises 25 members of whom 15 are judges - the postulate by the Council of Europe is fulfilled then.

The situation in Poland has recently changed in connection with passing a new Act on the National Council of the Judiciary ${ }^{44}$. Although the constitutional requirements in the strict sense were met, doubts are currently raised, however ${ }^{45}$, by the manner of appointing the members of the NCJ who are judges. Before the changes in the NCJ, the composition of 15 judicial members was chosen with respect to the principle of the representation of every type of court and every instance (with the exception of the district) in Poland ${ }^{46}$. The General Assemblies of judges of individual members chose their representation. And according to this rule, the judges

43 Constitution of the Republic of Poland of 2 April 1997 (Dz.U. 1997 nr 78 poz. 483/ Journal of Laws of 1997 No. 78 item 483).

44 Act of 8 December 2017 on Amending the Act on the National Council of the Judiciary and Certain Other Acts (Dz.U. 2018 poz. 3 / Journal of Laws of 2018 item 3).

45 This was criticised by such authorities as the Ombudsman Adam Bodnar, the members of the former Council, Polish judges association "Iustitia", "Themis" and many others.

46 Act of 12 May 2011 on the National Council of the Judiciary (Dz.U. 2011 nr 126 poz. 714 / Journal of Laws of 2011 No. 126 item 714). 
of the Supreme Court elected 2 members of the NCJ, the judges of the NAC, together with the representatives of voivodship administrative courts, chose 2 members, the judges of courts of appeal elected 2 representatives for the Council, the judges of regional courts chose 8 judges for the Council, and the military judges chose $1 \mathrm{mem}$ ber of the Council. The judges of district courts did not their representation in this system, which may result from the still little experience of judges of this instance. Such a solution guaranteed that the members of the judicial part on the NCJ would actually be a representation of the judiciary in that institution.

When on 8 December 2017 the amendment to the Act on the National Council of the Judiciary was passed, the situation changed radically. That is because the rule of electing members representing the judiciary by their peers was changed in favour of the election of the judges' representatives by the Sejm. At the moment, the Sejm elects the judges-members of the NCJ for a joint term of 4 years, with the majority of $3 / 5$ of votes, and if that majority is not reached, another voting occurs in which an absolute majority is sufficient.

Candidates for the judges-members of the NCJ may be submitted by a group of 2 thousand Polish citizens or a group of 25 judges, excluding retired judges (Article $11 a^{47}$ ). From the candidates selected by the previously mentioned groups, each parliamentary club chooses not more than 9 representatives for the Council. Then, a relevant Sejm committee establishes a list of 15 candidates, including at least 1 candidate selected by each parliamentary club on the list.

This solution is questionable at the very least because it is not difficult to conclude that the judges elected by the Sejm and not judges will represent the judiciary much worse on the Council itself. From the present formula, it may be concluded that the judges-members elected by the Sejm represent the parliamentary clubs and not - as they should - the judiciary. The originators of this solution refer to the legitimisation of the election - the Sejm consists of members elected democratically, while on the other hand, judges in no way have such legitimisation, and they should have it because the Republic of Poland is a democratic state, and representatives of all the powers should be elected this way. However, it is not difficult to see the deficits of such an attitude, which was described in more detail i.a. by J. Zajadło in his publication ${ }^{48}$.

47 Act of 8 December 2017 on Amending the Act on the National Council of the Judiciary and Certain Other Acts (Dz.U. 2018 poz. 3 / Journal of Laws of 2018 item 3).

48 J. Zajadło, Fałszywość hasła "Demokracja, a nie sędziokracja” - analiza filozoficzno-prawna, „Krajowa Rada Sądownictwa" 2017, No. 3(36), pp. 5-12. 
A constitutional court in the Republic of Poland is the Constitutional Tribunal. Article 194 of the Constitution of the Republic of Poland ${ }^{49}$ defines it precisely that the Constitutional Tribunal is composed of 15 judges appointed by the Sejm for a term of 9 years. The choice is individual which means that any judge is appointed for a nine-year term, even if he or she replaces a judge who left the Tribunal before his or her term ended ${ }^{50}$. Candidates for the position of a CT judge are presented by the the Sejm Presidium or by a group of at least 50 deputies, and the selection is made only by the Sejm by voting, with the requirement for an absolute majority of votes ${ }^{51}$. As it can be seen, the process of electing judges is very politicised, which, however, does not deviate from the solutions adopted in other countries. An interesting solution was postulated by Professor Strzembosz ${ }^{52}$. It involved performing the CT's tasks by a separate chamber of the Supreme Court, an institution which is considerably less politicised. This postulate, however, was not adopted.

\section{The competence of the Council and the procedure of appointing judges}

\section{Federal Republic of Germany}

In Germany, the committee for the appointment of judges is presided over by an appropriate federal minister. As previously stated, the selection of a minister who will preside over the committee depends strictly on the type of court - and in the Federal Labour Court, it will be the Minister of Labour, and in the Federal Administrative Court, it will be the Minister of Interior. Importantly, despite the fact of the federal minister's presiding over the committee, he or she has no right to vote at the moment of appointing a judge.

Obviously, the first step is to mark a proper candidate for a judge. The candidates may be suggested by both the members of the committee and a relevant federal minister. The eole of the committee is, among other things, to check whether a given candidate fulfils both the substantive and personal conditions required for a judicial nomination. Some participation in the process was also assigned to the Presidium of a given federal court, however, the Presidium only issues an

49 Constitution of the Republic of Poland of 2 April 1997 (Dz.U. 1997 nr 78 poz. 483/Journal of Laws of 1997 No. 78 item 483).

50 L. Garlicki, op. cit., p. 414.

51 Ibidem, p. 415.

52 A. Strzembosz, S. Zakroczymski, Między Prawem i Sprawiedliwością, Warsaw 2017, pp. 228-229. 
opinion on the candidate, and that opinion is not binding. Next, appropriate voting is conducted, in which a simple majority of votes is required. The candidate must be accepted by the relevant federal minister - it is essential to note here that the minister has a specific right to veto the choice at his or her disposal ${ }^{53}$. This results in a situation in which the committee for the appointment of judges, and the relevant minister must reach a consensus. The process ends with the nomination of the chosen judge by the President of the Republic.

\section{French Republic}

As previously mentioned, the body established to mark judges is the Superior Council of the Magistracy. It is entitled to issuing opinions which are binding in terms of the appointment of judges, with the exception of the judges of the Court of Cassation, the first presidents of courts of appeal, and the presidents of high courts ${ }^{54}$. In the case of those judges, the SCM's opinion is only an application which is not binding by the appointment of those judges. The SCM is a Professional Conduct Committee for judges, and it is then presided over by the First President of the Court of Cassation.

At the beginning, a candidate must complete training at the French National School for the Judiciary (French: École nationale de la magistrature), then his or her candidacy is considered by the Superior Council of the Magistracy. It is required that the candidate receive a positive assessment from the SCM - other authorities cannot appoint the candidate as a judge without the SCM's prior approval. Importantly, the SCM does not participate in the appointment of administrative judges ${ }^{55}$ (who are appointed only on the basis of exams, without the Council's opinion). The judges of lower instances are nominated by the Minister of Justice.

In the situation of promoting judges to higher instances, the process is conducted by a judicial committee that then obligates the Minister of Justice to issue an opinion on the candidate. At the very end of the entire process, the President of the Republic officially appoints the candidates as judges.

53 Interview with Professor Oliver Dörr conducted by Professor Fryderyk Zoll which was printed in "Gazeta Wyborcza", Jak zostaje się sędzią w Niemczech? Czy to porównanie jest uzasadnione?, Cracow, 21 July 2017.

54 P. Sarnecki, Ustroje konstytucyjne państw wspótczesnych, Warsaw 2008, p. 260.

55 M. Bobokhidze, Ensuring judicial independence through appointment of judges by council for the judiciary: Georgia, France, Budapest 2012, p. 32. 


\section{Republic of Poland}

A body responsible for the election of judges in Poland is the National Council of the Judiciary. The appointment of judges alone is the exclusive prerogative of the President of the Republic of Poland, established in Article 144 section $17^{56}$. That issue raised many controversies in the doctrine ${ }^{57}$. The process of appointing judges in Poland is presented below, and it was i.a. described in the Act - the Law on the System of Common Courts ${ }^{58}$.

In current legal regulations, candidacies are submitted by those who are interested in a specific position in a court in which there is a vacancy. If all formal requirements are fulfilled, the President of the court who received the application designates a judge who will assess the candidate. Next, such candidacy is considered by the General Assembly of the court which that candidacy concerns (except for district courts which do not have any Assembly - in this case, the candidacy is considered by the General Assembly of the Regional Court ${ }^{59}$ ). Voting is conducted, and its result is the issuance of an opinion ${ }^{60}$. It should be noted here that the opinion is non-binding, and it is only a specific hint for the authorities which will consider the candidacy at later stages of the procedure. Then, the candidacy is sent to the National Council of the Judiciary. At the beginning, it designates an assembly (from the Council members) to assess the candidate. The assembly must pass a regulation by the absolute majority of votes, and then the candidacy is considered for examination and assessment by the Council. The NCJ as a whole decides on an applicable regulation. It is the Council that decides which candidacies should be passed to the President of the Republic of Poland ${ }^{61}$. The President has no power to decide on his or her own who will become a judge - he or she has to act on request of the National Council of the Judiciary. However, what is important is the fact upon

56 Constitution of the Republic of Poland of 2 April 1997 (Dz.U. $1997 \mathrm{nr} 78$ poz. 483 / Journal of Laws of 1997 No. 78 item 483).

57 M. Ziółkowski, Prerogatywa Prezydenta RP do powotywania sędziów (uwagi o art. 144 u. 3 pkt 17 i art. 179 Konstytucji), Warsaw 2013.

58 Act of 27 July 2001 - Law on the System of Common Courts (Dz.U. 2001 nr 98 poz. 1070 / Journal of Laws of 2001 No. 98 item 1070).

59 In Polish: Zgromadzenie Ogólne Sądu Okręgowego [translator's note].

60 L. Garlicki, op. cit., pp. 400-401.

61 B. Pilitowski, M. Hoffman, B. Kociołowicz-Wiśniewska, Skąd się biorą sędziowie?, Report by Court Watch Poland Foundation. 
receiving the request from the $\mathrm{NCJ}$, he or she has no obligation to appoint such a candidate ${ }^{62}$, which was the case i.a. in 2016.

\section{Conclusions}

The process of electing judges in France, Germany and Poland varies significantly. The requirements of the Council of Europe's recommendation are best fulfilled by Poland. That is because judges constitute over half of the composition of the Council. What is problematic here is the fact that after the recent changes to the Act on the National Council of the Judiciary, the election of the judicial representation was changed, which made them no longer represent the judicial self-government in the literal meaning - they were not chosen by judges for the purpose of representation, but by the Sejm. Looking at the issue from this perspective, it may be concluded that the recommendation of the Council of Europe has not been put to practice here. This is because the ratio legis of the requirement of half the Council as judges is that they speak with the voice of judges. As of now, one may risk a claim (on the basis of the manner of selecting) that 15 judges speak more with the voice of the lower house of the parliament, which, given the fact that the Council is composed of 25 persons, already deviates from international standards.

The situation looks different in France. Admittedly, 5 judges (out of 12 members) sit on the Council there, however, they represent the judiciary more adequately. An essential factor should be added here, which, however, is impossible to measure or estimate - legal and political culture is discussed here ${ }^{63}$. Even if from the purely formal and procedural point of view, it may be concluded that the legislative and the executive have a crucial impact on the election of judges, the legal culture causes decisions to be made with respect to the principle of the independence of courts and judges, without being driven by one's private, political interest. This is a feature typical of the so-called old democracies. In the new ones, a requirement emerged for the procedural independence to be guaranteed more strongly, as the legal culture has not managed to develop in those countries yet (and Poland is undoubtedly one of such countries).

In Germany, when federal judges are appointed, a political voice is largely of importance. The committee for the appointment of judges is comprised exclusively

62 Ruling of the Supreme Administrative Court, ref. no. I OSK 857/17, I OSK 858/17, in which the court stated that presidential prerogatives are not controlled by the administration.

63 European Commission for Democracy through law, Judicial Appointment, Opinion no. 403/006, Venice 2007. 
of representatives of the legislative and the executive, the Lands are one half of it, the federal states are the other half. The Federal Minister also was not left without decision-making power. Preserving the idea of pluralism is a regulating factor so that given views do not dominate over others. Also - as mentioned above - the legal culture plays a substantial role here.

It is wrong to assume that one system is objectively the best and it should be used everywhere. Unmeasurable factors, which depend exclusively on certain cultural assumptions adopted in a given country, play a huge role here. There are obviously certain solutions which should be adopted everywhere in order to guarantee judicial independence, but copying the solutions adopted in other other countries 1 to 1 (or referring to such solutions) - which, among other things, is what the current Sejm majority in the Republic of Poland is doing - is a mistake because this results in ignoring many essential elements which frequently play a much bigger role than the norms included in the Constitution and acts.

\section{Bibliografia}

Bobokhidze M., Ensuring judicial independence through appointment of judges by council for the judiciary: Georgia, France, Budapeszt 2012.

Dąbrowski S., Władza sądownicza - definicja, funkcje atrybuty, w: Pozycja ustrojowa sędziego, red. R. Piotrowski, Warszawa 2015.

Izdebski H., Doktryny polityczno-prawne, Warszawa 2017.

Garlicki L., Polskie Prawo Konstytucyjne, Warszawa 2017.

Garoupa N., Ginsburg T., The comparative law and economics of judicial councils, "Berkley Journal of International Law" 2009, nr 1.

Konstytucja. Komentarz, t. II, red. M. Safjan, L. Bosek, Warsaw 2016.

Łazarska A., Niezawisłość sędziowska w sprawowaniu urzędu, w: Pozycja ustrojowa sędziego, red. R. Piotrowski, Warszawa 2015.

Pilitowski B., Hoffman M., Kociołowicz-Wiśniewska B., Skąd się biorą sędziowie?, Raport fundacji Court Watch Polska.

Sarnecki P., Ustroje konstytucyjne państw wspótczesnych, Warszawa 2008.

Strzembosz A., Zakroczymski S., Między Prawem i Sprawiedliwościq, Warszawa 2017.

Tuleja P., Konstytucyjny status Krajowej Rady Sąownictwa, w: Jubileuszowa monografia XX-lecia Krajowej Rady Sądownictwa, red. P. Tuleja, Torun-Warszawa 2010.

Volcansek M.L., Appointing Judges the European Way, "Fordham Urban Law Journal" 2007, No. 1, Vol. 34.

Zawistowski D., Niezależność sądów i niezawistość sędziów z perspektywy prawa Unii Europejskiej, „Ruch Prawniczy, Ekonomiczny, Socjologiczny” 2016, nr 2.

Zajadło J., Fatszywość hasła "Demokracja, a nie sędziokracja" - analiza filozoficzno-prawna, „Krajowa Rada Sądownictwa” 2017, No. 3(36), pp. 5-12. 


\section{KRZYSZTOF PASIERBEK}

Ziółkowski M., Prerogatywa Prezydenta RP do powotywania sędziów (uwagi o art. 144 u. 3 pkt 17 i art. 179 Konstytucji), Warszawa 2013.

Zoll F., Jak zostaje się sędzią w Niemczech? Czy to porównanie jest uzasadnione?, "Gazeta Wyborcza", 21 lipca 2017. 